\title{
Tanggap fungsional Menochilus sexmaculatus Fabricius (Coleoptera: Coccinellidae) terhadap Aphis gossypii (Glover) (Homoptera: Aphididae) pada umur tanaman cabai berbeda
}

\author{
Functional response of Menochilus sexmaculatus Fabricius \\ (Coleoptera: Coccinellidae) on Aphis gossypii (Glover) \\ (Homoptera: Aphididae) at different ages of chili plants
}

\author{
Novri Nelly*, Trizelia, Qorry Syuhadah \\ Jurusan Hama dan Penyakit Tumbuhan, Fakultas Pertanian Universitas Andalas, \\ Kampus Unand Limau Manih, Padang 25163
}

(diterima Februari 2012, disetujui Maret 2012)

\begin{abstract}
ABSTRAK
Kumbang predator Menochilus sexmaculatus merupakan salah satu agens hayati yang dapat digunakan untuk mengendalikan kutudaun. Walaupun demikian, informasi mengenai keefektifan kumbang tersebut dalam menekan populasi kutudaun belum banyak diketahui. Penelitian ini bertujuan mempelajari tanggap fungsional $M$. sexmaculatus dengan menggunakan mangsa Aphis gossypii pada berbagai kerapatan $(10,20,30,40$, dan 50 individu). Seluruh mangsa dipaparkan pada satu imago $M$. sexmaculatus selama 1 jam pada 4 tingkatan umur cabai yang berbeda yaitu 2, 4, 6, dan 8 minggu. Data dianalisis menggunakan analisis sidik ragam dan regresi logistik untuk menentukan tipe tanggap fungsional predator. Hasil penelitian menunjukkan bahwa kemampuan memangsa $M$. sexmaculatus tidak berbeda nyata pada tanaman cabai umur 2 dengan 4 minggu dan 6 dengan 8 minggu. Tanggap fungsional M. sexmaculatus terhadap A. gossypii pada tanaman cabai umur 2 minggu adalah tipe I, sedangkan umur 4, 6, dan 8 minggu adalah tipe III.
\end{abstract}

Kata kunci: pengendalian hayati, predator, kemampuan pemangsaan

\begin{abstract}
The lady beetle, Menochilus sexmaculatus is one of the biological control agents that can be used to control aphids. Presently, there is a lack of information about the effectiveness of this beetle to control aphids. The objective of this research was to study the functional response of $M$. sexmaculatus on Aphis gossypii at different ages of plants. All preys were exposed to one M. sexmaculatus adult for an hour at five different densities of aphids $(10,20,30,40$, and 50 individuals) is four different ages of chilli plants $(2,4,6$, and 8 weeks). Data were analyzed by ANOVA and logistic regression to determine the type of functional response. The results showed that the ability of $M$. sexmaculatus to prey was not significant at 2 to 4 and 6 to 8 weeks old chilli plants. At 2 week old chilli plants M. sexmaculatus showed type I of functional response, while at 4, 6 and 8 weeks the functional response were type III.
\end{abstract}

Key words: feeding capacity, predator, biological control

\footnotetext{
${ }^{*}$ Penulis korespondensi: Novri Nelly. Jurusan Hama dan Penyakit Tumbuhan, Fakultas Pertanian, Universitas Andalas, Kampus Unand Limau Manih, Padang 25163

Tel: 0751-72701, Faks: 0751-72702, Email: novrinelly@yahoo.com
} 


\section{PENDAHULUAN}

Kutudaun Aphis gossypii Glover (Homoptera: Aphididae) merupakan salah satu hama yang menyerang tanaman cabai, disamping hama penting lain seperti Myzus persicae Sulz., ulat grayak Spodoptera litura F. (Lepidoptera: Noctuidae), lalat buah Bractocera dorsalis H. (Diptera: Tephtritidae), Thrips sp. (Thysanoptera: Thripidae), dan tungau Tetranychus bimaculatus Harvey. (Acarina) (Suyanto 1994). Serangan A. gossypii biasanya terjadi pada awal musim kemarau yaitu saat udara kering dan suhu tinggi. Bagian tanaman yang diserang biasanya pucuk tanaman dan daun muda. Serangga ini akan bergerombol sehingga mampu menutupi bagian tanaman (Aripin \& Lubis 2003). Satu individu A. gossypii dewasa dapat menghasilkan keturunan 50 individu dalam waktu satu minggu. Oleh karena itu, ledakan populasi dapat terjadi sewaktu-waktu dengan cepat dan dapat menjadi ancaman yang serius. Serangan berat akan menyebabkan tanaman cabai menjadi mengerdil (Mardiningsih \& Soetopo 1999).

Pengendalian hama kutudaun biasanya dengan memanfaatkan musuh alami. Musuh alami merupakan salah satu komponen dalam pengendalian hama terpadu (PHT), sehingga penelitian pemanfaatan musuh alami (predator, parasitoid dan cendawan entomopatogen) sangat penting untuk mendukung keberhasilan pengendalian hama tanaman yang berwawasan lingkungan. Salah satu predator yang dapat digunakan untuk memangsa kutudaun adalah Menochilus sexmaculatus (Coleoptera: Coccinellidae). Predator ini dikenal sangat rakus dalam memangsa jenis kutudaun. Sepasang kumbang ini dapat memangsa kutudaun sebanyak 50-200 individu dalam sehari (Nelly et al. 2007). Hasil penelitian Omkar dan Bind (2004) dan Omkar et al. (2005) menunjukkan bahwa M. sexmaculatus efektif mengendalikan serangan hama kutudaun. Walaupun demikian, keefektifan predator dalam memangsa sangat bergantung kepada kemampuan mencari dan menangani mangsanya pada keadaan lingkungan tertentu. Keadaan suhu, kelembaban, luas areal pencarian atau umur tanaman dan kerapatan mangsa sangat mempengaruhi keefektifan predator dalam pengendalian (Godfray 1994; Nelly et al. 2005).
Tanggap fungsional merupakan salah satu ukuran untuk menentukan keefektifan suatu predator dalam pengendalian hayati. Pada awalnya tanggap fungsional dikembangkan dari model pemangsaan predator (Rogers 1972). Istilah ini pertama kali diperkenalkan oleh Solomon pada tahun 1949 (Sharov 1996) untuk menyatakan jumlah mangsa yang diserang oleh predator pada kerapatan populasi mangsa per satuan waktu. Tanggap fungsional merupakan komponen yang sangat esensial dalam hubungan predator dan mangsanya, karena dapat memberi gambaran mengenai potensi predator tersebut dalam mengendalikan populasi mangsanya.

Tanggap fungsional dibedakan atas tiga tipe. Tipe I atau tipe tanggap fungsional linear merupakan laju pemangsaan meningkat atau menurun sehubungan dengan peningkatan atau penurunan populasi mangsa. Tipe I ini biasanya ditemukan pada predator yang bersifat pasif seperti laba laba. Jumlah laba laba yang terperangkap pada jaring laba laba akan sebanding dengan kerapatan populasi lalat (Sharov 1996). Pada tipe II atau tanggap fungsional hiperbolik, laju pemangsaan menurun dengan meningkatnya kerapatan mangsa, mortalitas mangsa maksimal terjadi pada kerapatan mangsa yang rendah. Sedangkan tipe III atau tanggap fungsional sigmoid, pada awalnya peningkatan pemangsaan berlangsung lambat, diikuti dengan peningkatan yang lebih cepat, kemudian konstan (Sharov 1996; Nelly et al. 2005)

Kerapatan mangsa dan bentuk tanaman yang berbeda akan mempengaruhi kinerja predator sebagai agens hayati. Ukuran atau umur tanaman sangat mempengaruhi tanggap fungsional predator dalam mengendalikan populasi mangsa. Kemampuan memangsa predator Podisus nigrispinus (Heteroptera: Pentatomidae) terhadap Spodoptera exigua pada tanaman lada, terung dan tomat memperlihatkan perbedaan. Tipe tanggap fungsional predator ini adalah tipe II pada lada dan terung, sedangkan pada tanaman tomat adalah tipe III (De Clereq et al. 2000).

Studi mengenai keefektifan M. sexmaculatus sebagai agens hayati berdasarkan tipe tanggap fungsionalnya masih belum banyak dipelajari. Oleh karena itu melalui penelitian ini akan dipelajari bagaimana kemampuan memangsa 
kumbang predator $M$. sexmaculatus terhadap kutudaun, A. gossypii pada berbagai tingkatan umur tanaman cabai.

\section{BAHAN DAN METODE}

\section{Pengadaan tanaman dan serangga mangsa}

Tanaman yang digunakan adalah tanaman cabai lokal. Benih cabai lokal disemaikan langsung pada tempat penyemaian di dekat lahan petani di daerah Binuang, Kecamatan Pauh Kuranji, Padang. Bibit cabai yang sudah siap untuk ditanam (umur 3 minggu) langsung dipindahkan ke dalam polybag yang berdiameter $10 \mathrm{~cm}$ di rumah kawat. A. gossypii sebagai mangsa dikumpulkan dari tanaman cabai di lokasi yang sama dengan asal tanaman cabai, kemudian dipelihara pada tanaman cabai yang ditanam pada polybag di rumah kawat.

\section{Pengadaan serangga predator}

M. sexmaculatus dikumpulkan dari lapangan pada pertanaman cabai dan dimasukkan ke dalam kurungan serangga yang berukuran $30 \mathrm{~cm}$ x $30 \mathrm{~cm}$ x $30 \mathrm{~cm}$ di rumah kawat. Dalam kurungan diletakkan tanaman cabai (umur 1-2 bulan). Pada tanaman cabai tersebut dipaparkan $A$. gossypii sebagai pakan M. sexmaculatus. Pemeliharaan dilakukan sampai muncul imago baru. Imago yang berumur 2 hari dijadikan sebagai serangga uji.

\section{Kemampuan pemangsaan dengan memangsa pada umur tanaman cabai berbeda}

Pada setiap masing-masing tanaman cabai dengan umur yang berbeda yaitu 2, 4, 6, dan 8 minggu dimasukkan satu imago $M$. sexmaculatus betina. Imago terlebih dahulu dilaparkan selama 5 jam dengan tujuan agar saat diletakkan pada tanaman, predator tersebut dapat langsung memangsa kutudaun. A. gossypii yang digunakan sebanyak 10, 20, 30, 40, dan 50 individu, kemudian diletakkan dalam kurungan serangga yang berukuran $30 \mathrm{~cm} \times 30 \mathrm{~cm} \times 60 \mathrm{~cm}$. Pengamatan dilakukan selama satu jam kemudian diamati kemampuan memangsa dan laju pemangsaan $M$. sexmaculatus. Setiap satuan percobaan diulang 5 kali.

Kemampuan memangsa $M$. sexmaculatus diamati di bawah kondisi laboratorium secara langsung. Pemangsaan diamati dengan menghitung jumlah $A$. gossypii yang di mangsa selama satu jam serta waktu yang dibutuhkan M. sexmaculatus dalam penanganan 1 individu mangsa.

\section{Analisis data}

Pengamatan dilakukan dengan menghitung waktu $M$. sexmaculatus untuk menemukan dan memangsa A. gossypii. Selanjutnya data hasil penelitian dihitung berdasarkan Holling (1959) yaitu $\mathrm{Na}=\mathrm{aTN} /(1+\mathrm{aThN})$ dengan Na: jumlah kutudaun yang dimangsa, a: laju pemangsaan, $\mathrm{T}$ : lama pemangsaan (60 menit), $\mathrm{N}$ : kerapatan mangsa dan Th: waktu yang digunakan predator untuk menangani satu mangsa.

Penentuan tipe tanggap fungsional adalah dengan menggunakan analisis regresi, yaitu dengan menghitung jumlah $A$. gossypii yang dimangsa (Ne) dan dibandingkan dengan yang dipaparkan (No). Data pemangsaan dianalisis menggunakan regresi linear, eksponensial dan logaritmik. Nilai $r$ digunakan untuk menentukan tipe tanggap fungsional, dari setiap persamaan regresi yang digunakan. Nilai $r$ yang paling mendekati 1 dinyatakan sebagai tipe respon fungsional dari predator (Jones et al. 2003).

\section{HASIL}

Kemampuan memangsa $M$. sexmaculatus pada beberapa kerapatan mangsa dan umur tanaman cabai berbeda

Kemampuan memangsa $M$. sexmaculatus terhadap A. gossypii dipengaruhi oleh kerapatan mangsa, akan tetapi umur tanaman cabai berpengaruh secara tidak nyata. Terlihat adanya interaksi antara kerapatan mangsa dan umur tanaman terhadap kemampuan memangsa $M$. sexmaculatus. Kemampuan memangsa meningkat dengan meningkatnya kerapatan mangsa pada masing masing umur yang berbeda, akan tetapi tidak terdapat perbedaan yang nyata pada kerapatan mangsa yang rendah (Tabel 1).

Tanaman cabai umur 2 dan 4 minggu, 6 dan 8 minggu tidak memperlihatkan perbedaan yang nyata (Tabel 1). Pada perlakuan umur tanaman cabai 2 minggu, satu individu predator $M$. sexmaculatus mampu memangsa kutudaun $A$. gossypii sampai 44,50 individu/jam jika mangsa yang diberikan 50 individu. Kemampuan memangsa 
Tabel 1. Kemampuan memangsa Menochilus sexmaculatus pada beberapa kerapatan Aphis gossypii. Data dalam rerata \pm standar deviasi. Huruf yang sama pada kolom yang sama berbeda nyata dengan uji Tukey pada taraf nyata $5 \%$

\begin{tabular}{crrrcc}
\hline \multirow{2}{*}{$\begin{array}{c}\text { Umur tanaman } \\
\text { (minggu) }\end{array}$} & \multicolumn{5}{c}{ Kerapatan mangsa (individu/jam) } \\
\cline { 2 - 6 } & 10 & 20 & 30 & 40 & 50 \\
\hline 2 & $10,00 \pm 0,00 \mathrm{a}$ & $20,00 \pm 0,00 \mathrm{a}$ & $29,75 \pm 0,50 \mathrm{a}$ & $38,00 \pm 2,16 \mathrm{a}$ & $44,50 \pm 1,91 \mathrm{a}$ \\
4 & $10,00 \pm 0,00 \mathrm{a}$ & $19,50 \pm 1,00 \mathrm{a}$ & $28,25 \pm 1,25 \mathrm{a}$ & $36,25 \pm 2,06 \mathrm{a}$ & $40,00 \pm 4,24 \mathrm{a}$ \\
6 & $6,00 \pm 1,29 \mathrm{~b}$ & $12,75 \pm 2,22 \mathrm{~b}$ & $19,25 \pm 1,89 \mathrm{~b}$ & $26,25 \pm 3,59 \mathrm{~b}$ & $28,25 \pm 3,59 \mathrm{~b}$ \\
8 & $3,75 \pm 1,71 \mathrm{~b}$ & $11,25 \pm 2,63 \mathrm{~b}$ & $15,50 \pm 2,30 \mathrm{~b}$ & $22,75 \pm 3,30 \mathrm{~b}$ & $24,75 \pm 4,99 \mathrm{~b}$ \\
\hline
\end{tabular}

Tabel 2. Laju pemangsaan predator pada beberapa tingkatan umur tanaman cabai. Huruf yang sama pada kolom yang sama berbeda nyata dengan uji Tukey pada taraf nyata $5 \%$

\begin{tabular}{cccccc}
\hline \multirow{2}{*}{$\begin{array}{c}\text { Umur tanaman } \\
\text { (minggu) }\end{array}$} & \multicolumn{5}{c}{ Laju pemangsaan (individu x $10-4 /$ menit) } \\
\cline { 2 - 6 } & 10 & 20 & 30 & 40 & 50 \\
\hline 2 & $2,79 \mathrm{a}$ & $2,79 \mathrm{a}$ & $2,77 \mathrm{a}$ & $2,65 \mathrm{a}$ & $2,49 \mathrm{a}$ \\
4 & $2,79 \mathrm{a}$ & $2,72 \mathrm{a}$ & $2,63 \mathrm{a}$ & $2,53 \mathrm{a}$ & $2,24 \mathrm{a}$ \\
6 & $1,81 \mathrm{~b}$ & $1,78 \mathrm{~b}$ & $1,79 \mathrm{~b}$ & $1,84 \mathrm{~b}$ & $1,58 \mathrm{~b}$ \\
8 & $1,05 \mathrm{~b}$ & $1,57 \mathrm{~b}$ & $1,44 \mathrm{~b}$ & $1,59 \mathrm{~b}$ & $1,38 \mathrm{~b}$ \\
\hline
\end{tabular}

Tabel 3. Tipe tanggap fungsional Menochilus sexmaculatus pada umur tanaman cabai yang berbeda berdasarkan analisis regresi dan nilai $r$

\begin{tabular}{|c|c|c|c|}
\hline $\begin{array}{l}\text { Umur tanaman } \\
\text { (minggu) }\end{array}$ & Persamaan regresi & Nilai $R^{2}$ & $\begin{array}{l}\text { Tipe tanggap } \\
\text { fungsional }\end{array}$ \\
\hline \multirow[t]{3}{*}{2} & $\begin{array}{l}\text { Regresi linier } \\
\mathrm{Y}=0.87 \mathrm{x}+2.35\end{array}$ & 0.9928 & \multirow{5}{*}{ Tipe I } \\
\hline & $\begin{array}{l}\text { Regresi eksponensial } \\
\mathrm{Y}=8.4701 \mathrm{e}^{0.0363 \mathrm{x}}\end{array}$ & 0.9926 & \\
\hline & $\begin{array}{l}\text { Regresi logaritmik } \\
\mathrm{Y}=21.443 \ln (\mathrm{x})-41.458\end{array}$ & 0.9222 & \\
\hline \multirow[t]{3}{*}{4} & $\begin{array}{l}\text { Regresi linier } \\
\mathrm{Y}=0.7675 \mathrm{x}+3.775\end{array}$ & 0.9798 & \\
\hline & $\begin{array}{l}\text { Regresi eksponensial } \\
\mathrm{Y}=8.6789 \mathrm{e}^{0.0339 \mathrm{x}}\end{array}$ & 0.9083 & \\
\hline & $\begin{array}{l}\text { Regresi logaritmik } \\
\mathrm{Y}=19.114 \ln (\mathrm{x})-35.512\end{array}$ & 0.9817 & Tipe III \\
\hline \multirow[t]{3}{*}{6} & $\begin{array}{l}\text { Regresi linier } \\
\mathrm{Y}=0.87 \mathrm{x}+2.35\end{array}$ & 0.9629 & \multirow{5}{*}{ Tipe III } \\
\hline & $\begin{array}{l}\text { Regresi eksponensial } \\
\mathrm{Y}=5.4658 \mathrm{e}^{0.0366 \mathrm{x}}\end{array}$ & 0.9163 & \\
\hline & $\begin{array}{l}\text { Regresi logaritmik } \\
\mathrm{Y}=14.111 \ln (\mathrm{x})-27.402\end{array}$ & 0.9668 & \\
\hline \multirow[t]{3}{*}{8} & $\begin{array}{l}\text { Regresi linier } \\
\mathrm{Y}=0.87 \mathrm{x}+2.35\end{array}$ & 0.9729 & \\
\hline & $\begin{array}{l}\text { Regresi eksponensial } \\
Y=3.3864^{00.0448 x}\end{array}$ & 0.8626 & \\
\hline & $\begin{array}{l}\text { Regresi logaritmik } \\
Y=13.317 \ln (\mathrm{x})-27.814\end{array}$ & 0.9738 & Tipe III \\
\hline
\end{tabular}


akan menurun menjadi 24,75 individu/jam pada tanaman cabai yang telah berumur 8 minggu.

\section{Laju pemangsaan}

Laju pemangsaan $M$. sexmaculatus terhadap A. gossypii pada umur tanaman 2 dan 4 minggu serta 6 dan 8 minggu dengan jumlah mangsa yang berbeda menunjukkan perbedaan yang tidak nyata (Tabel 2). Kemampuan pemangsaan $M$. sexmaculatus pada setiap tingkatan umur tanaman yang sama, laju pemangsaan tidak menunjukkan perbedaan yang nyata. Demikian juga kerapatan mangsa tidak secara nyata mempengaruhi laju pemangsaan.

\section{Tipe tanggap fungsional}

Hasil analisis regresi untuk pemangsaan $M$. sexmaculatus yang diberikan mangsa dengan kerapatan yang berbeda menggambarkan tipe yang juga berbeda pada umur tanaman 2 dan 4 minggu serta 6 dan 8 minggu (Tabel 3). Tanggap fungsional $M$. sexmaculatus menunjukkan tanggap fungsional tipe I jika dilihat dari nilai $\mathrm{r}(\mathrm{r} \leq 1)$ masing-masing persamaan, tidak terlalu berbeda antara tipe I dengan tipe II (Gambar 1), sedangkan yang lainnya termasuk dalam tipe III (Gambar 2, 3 dan 4).

Penentuan tipe tanggap fungsional berdasarkan analisis regresi, menunjukkan perbedaan. Dari tiga bentuk persamaan regresi yang diuji terdapat perbedaan nilai $r$. Nilai $r$ menentukan tingkat keeratan dari masing masing persamaan. Nilai $r$ yang mendekati 1 digunakan sebagai dasar penentuan persamaan yang dipilih, dan penentu dari tipe fungsional respon (Jones et al. 2000). Tanaman cabai umur 2 minggu tipe

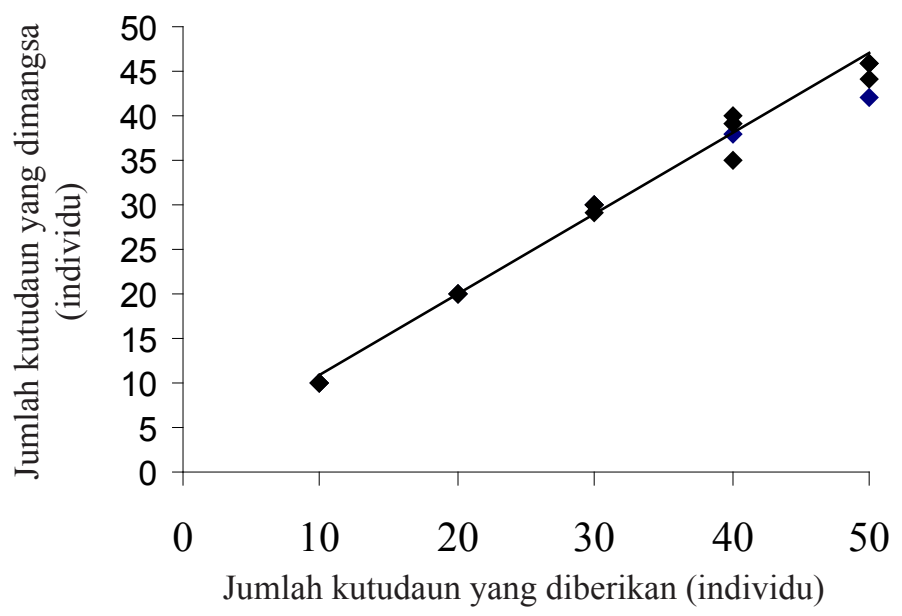

Gambar 1. Kemampuan memangsa Menochilus sexmaculatus terhadap beberapa kerapatan Aphis gossypii pada tanaman cabai umur 2 minggu

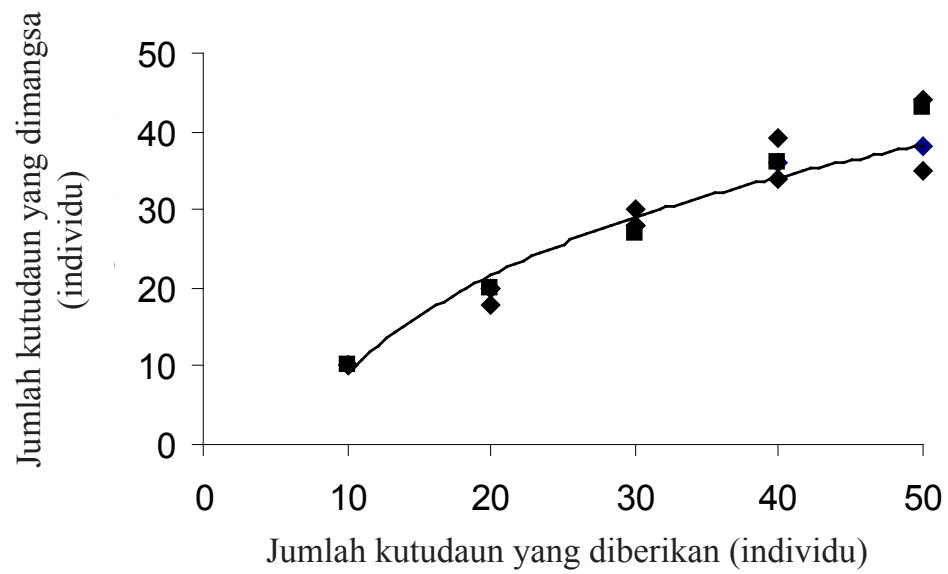

Gambar 2. Kemampuan memangsa Menochilus sexmaculatus terhadap beberapa kerapatan Aphis gossypii pada tanaman cabai umur 4 minggu 


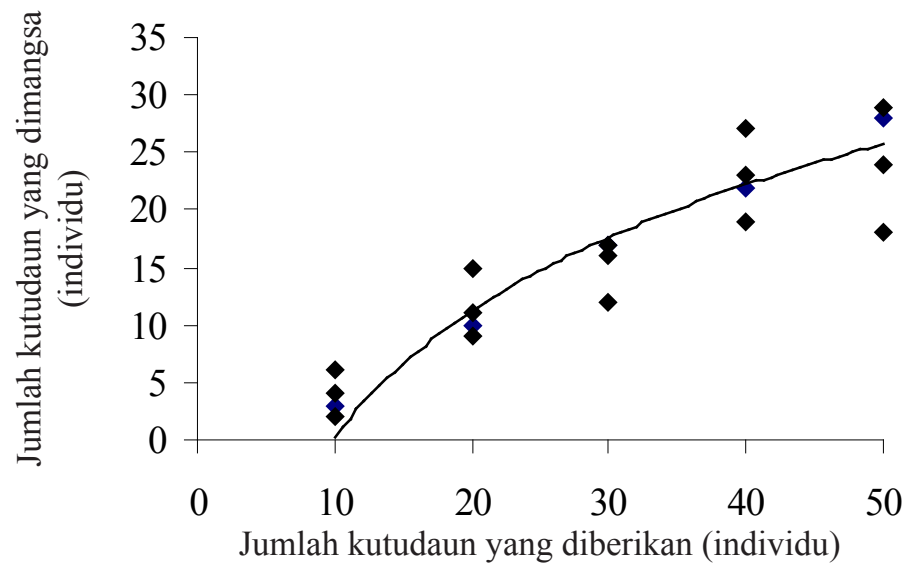

Gambar 3. Kemampuan memangsa Monechilus sexmaculatus terhadap beberapa kerapatan Aphis gossypii pada tanaman cabai umur 6 minggu

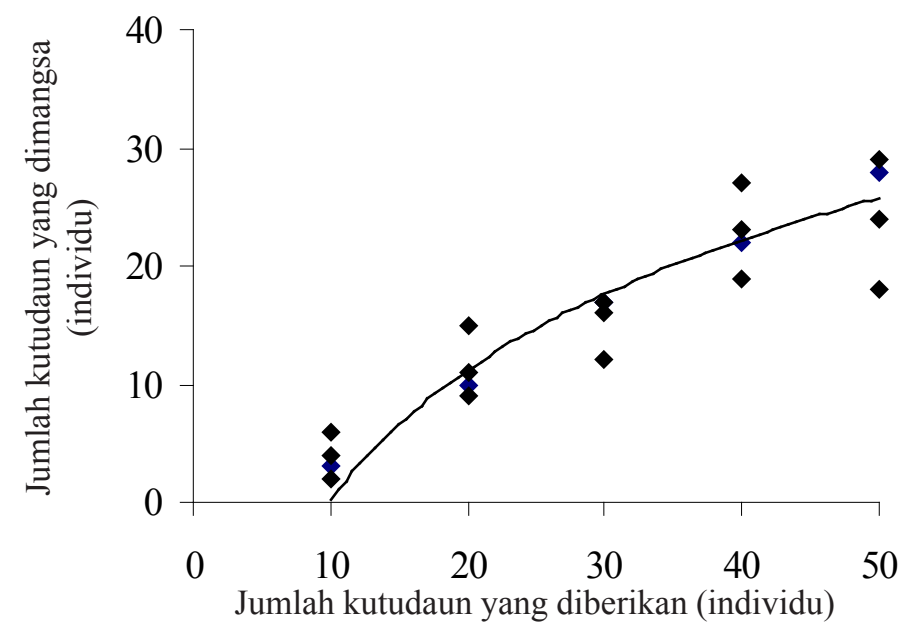

Gambar 4. Kemampuan memangsa Menochilus sexmaculatus terhadap beberapa kerapatan Aphis gossypii pada tanaman cabai umur 8 minggu

tanggap fungsionalnya adalah tipe $\mathrm{I}(\mathrm{r}=0,99)$

laju pemangsaannya meningkat atau menurun sehubungan dengan peningkatan atau penurunan mangsa (Tabel 2). Tanaman cabai umur 4, 6 dan 8 minggu tipe tanggap fungsionalnya adalah tipe III $(r=0,97)$ dimana pada awalnya peningkatan pemangsaan berlangsung lambat, diikuti peningkatan yang lebih cepat, kemudian konstan.

\section{PEMBAHASAN}

Dengan adanya perbedaan umur tanaman cabai terlihat perbedaan tanggap fungsional $M$. sexmaculatus. Pada umur tanaman 2 minggu menunjukkan tipe I yang cenderung ke tipe II. Hal ini dilihat dari nilai keeratan proporsi pemangsaan yang tidak terlalu berbeda. Secara umum kemampuan memangsa $M$. sexmaculatus meningkat dengan meningkatnya jumlah mangsa, terutama hal ini terjadi pada umur tanaman cabai 2 minggu. Akan tetapi secara statistik hal ini tidak menunjukkan perbedaan yang nyata. Laju pemangsaan tidak terlihat berbeda terutama pada waktu tanaman masih kecil (umur 2 dan 4 minggu). Diduga hal ini berhubungan dengan luas areal pencarian. Semakin kecil umur tanaman, biasanya jumlah daun masih belum banyak sehingga predator akan mudah mendapatkan mangsanya. Dalam penelitian ini tidak dihitung jumlah daun tanaman cabai pada masing masing tingkatan umur. Dari beberapa penelitian tampak bahwa selain suhu, umur dan bentuk tanaman juga akan mempengaruhi laju pemangsaan predator. Menurut De Clereq et al. (2000) bentuk tanaman sangat mempengaruhi $P$. nigrispinus predator dalam menangani $S$. exigua. Efisiensi pencarian 
pada lada dan terung adalah sama, akan tetapi berbeda dengan tomat.

Kemampuan pemangsaan predator pada perlakuan adalah sama, yaitu peningkatan jumlah kerapatan A. gossypii mengakibatkan daya mangsa semakin tinggi. Selanjutnya dapat dilihat adanya hubungan antara predator $M$. sexmaculatus terhadap kerapatan A.gossypii, semakin tinggi kerapatan $A$. gossypii semakin banyak jumlah individu $A$. gossypii yang dimangsa. Sesuai dengan pendapat Hodek dan Honek (1996) kemampuan predator untuk memangsa dan menyesuaikan sumber makanan sangat penting, jika predator tersebut efektif dalam mengendalikan mangsanya. Selanjutnya Holling (1959) dan Montoya (2000) menyatakan ada lima komponen yang mempengaruhi hubungan mangsa dengan predator atau inang dengan parasitoid yaitu kerapatan mangsa atau inang, kepadatan predator atau parasitoid, keadaan lingkungan (seperti adanya makanan alternatif), sifat mangsa (misalnya mekanisme mempertahankan diri dari serangan pemangsa, dan sifat predator (misalnya cara menyerang mangsa). Umur tanaman juga mempengaruhi kemampuan memangsa predator, semakin tinggi umur tanaman maka jumlah daun akan semakin banyak sehingga predator $M$. sexmaculatus semakin susah menemukan mangsanya.

Laju pemangsaan akan berpengaruh juga terhadap kemampuan memangsa $M$. sexmaculatus terhadap A. gossypii. Semakin tinggi laju pemangsaan $M$. sexmaculatus maka semakin banyak $A$. gossypii yang dimangsa. Dari Tabel 2 terlihat bahwa laju pemangsaan secara statistik tidak berbeda nyata. Laju pemangsaan pada tanaman cabai umur 2 dan 4 minggu dengan jumlah mangsa yang diberikan, yaitu 50 individu, ratarata 1-2 individu per menit. Jika dilihat pengaruh masing-masing perlakuan, yaitu umur tanaman cabai atau jumlah mangsa, terdapat hubungan tetapi tidak nyata antara umur tanaman cabai dengan jumlah mangsa yang diberikan. Akan tetapi pada kerapatan mangsa rendah, pemangsaan menghabiskan sebagian besar waktu mereka di pencarian, sedangkan pada kerapatan mangsa tinggi, predator menghabiskan sebagian besar waktu mereka untuk penanganan mangsa.

Sesuai dengan pendapat Hodek dan Honek (1996) bahwa adanya dua fenomena yang terjadi dalam peningkatan jumlah kutudaun yang dimangsa, yaitu pertama Coccinellidae yang lapar langsung memangsa saat pertama mangsa tersebut ditangkap. Fenomena kedua yaitu setelah peledakan mangsa secara bertahap akan menurunkan efiesiensi pemangsaan. Selanjutnya pendapat Frazer (1988) bahwa Coccinellidae tidak menangkap seluruh aphid yang ditemukan. Banyak aphid yang terpencar dari daerah pemangsaan yang terganggu karena perilaku mencari mangsa oleh Coccinellidae dalam merespon terhadap alarm feromon yang dikeluarkan aphid di sekitarnya (Nault \& Bowers 1978 dalam Frazer 1988).

Kemampuan memangsa dan laju pemangsaan M. sexmaculatus akan berpengaruh juga terhadap tipe tanggap fungsional yang terbentuk. Tanaman cabai umur 2 minggu tipe tanggap fungsionalnya adalah tipe I (Tabel 3), dimana M. sexmaculatus juga terlihat meningkat dengan peningkatan jumlah mangsa $\left(\mathrm{R}^{2}=0,99\right)$ nilai $\mathrm{Y}=0,87 \mathrm{x}+2,35$. Persamaan ini menggambarkan bahwa nilai 2,35 adalah konstanta (a), yang menunjukkan nilai variabel $Y$ jika $x=0$. Selanjutnya pemangsaan akan meningkat sebesar 0,87 jika $\mathrm{x}$ berubah satu satuan kerapatan mangsa. Tanggap fungsional tipe I atau tipe tanggap fungsional linier adalah laju pemangsaan meningkat atau menurun sehubungan dengan peningkatan atau penurunan kerapatan inang. Hal ini berhubungan dengan kemampuan memangsa $M$. sexmaculatus, dimana semakin kecil umur tanaman, maka semakin mudah $M$. sexmaculatus dalam mencari mangsa disebabkan karena ukuran tanaman yang belum terlalu tinggi, jumlah daun belum terlalu banyak, ukuran daun yang tidak terlalu luas sehingga $M$. sexmaculatus mudah dalam menemukan mangsanya.

Hasil pengamatan pada tanaman cabai umur 4, 6 dan 8 minggu, tipe tanggap fungsionalnya adalah tipe III. Tipe III dicirikan oleh awal peningkatan pemangsaan berlangsung lambat, diikuti peningkatan yang lebih cepat, kemudian konstan (Hassel 2000). Pada penelitian ini jumlah mangsa yang diberikan adalah melebihi jumlah optimal. Pada penelitian pendahuluan (Nelly et al. 2007) diketahui bahwa M. sexmaculatus mampu memangsa kutudaun sebanyak 50-200 individu/hari. Sedangkan pada penelitian ini pemaparan adalah selama 1 jam, jadi diduga akan menyebabkan predator ini jadi jenuh. Sehingga walaupun jumlah mangsa ditambahkan, akan 
tetapi laju pemangsaan akan konstan. Hal ini yang menjadi ciri dari tanggap fungsional tipe III.

Pada setiap umur tanaman yang berbeda tipe tanggap fungsionalnya juga berbeda. Hal ini dipengaruhi oleh kemampuan memangsa $M$. sexmaculatus terhadap $A$. gossypii, dan laju pemangsaan yang berbeda pula. Hasil penelitian Omkar (2004) menjelaskan bentuk tanggap fungsional Coccinellid predator, Chilomenes sexmaculata, Propylea dissecta, dan Coccinella transversalis (Coleoptera: Coccinellidae) pada 3 jenis mangsa yaitu tipe II. Akan tetapi terdapat perbedaan waktu penanganan oleh masing masing predator pada 3 mangsa tersebut.

\section{KESIMPULAN}

Kemampuan memangsa $M$. sexmaculatus tidak terlihat berbeda pada saat tanaman cabai berumur 2 dan 4 minggu. Demikian juga sama pada saat umur tanaman 6 dan 8 minggu. Tanggap fungsional $M$. sexmaculatus terhadap A. gossypii pada tanaman cabai umur 2 minggu bertipe I yaitu laju pemangsaan meningkat atau menurun sehubungan dengan peningkatan atau penurunan kerapatan inang, sedangkan pada umur 4, 6, dan 8 minggu bertipe III yaitu pada awalnya peningkatan pemangsaan berlangsung lambat, diikuti peningkatan yang lebih cepat, kemudian konstan.

\section{DAFTAR PUSTAKA}

Aripin K, Lubis L. 2003. Teknik pengelolaan hama terpadu (PHT) pada tanaman cabai (Capsicum annum L.) di dataran rendah. Available at: http:// www.library.usu. ac. id [diakses 9 September 2010]

De Clereq PD, Mohagheh J, Tirry L. 2000. Effect of host on functional response of predator Podisus nigripinus (Heteroptera: Pentatomidae) Biological Control 18:65-70. http://dx.doi org/10.1006/bcon.1999.0808.

Frazer BD. 1988. Aphids and their biology. In: Minks AK, Harrewijn P (Eds.), Natural enemies and control volume. pp 235-237. Oxford: Elsevier.

Godfray HCJ. 1994. Parasitoids, behavioral and evolutinary ecology. New Jersey: Princeton University Press.
Hassel MP. 2000. The spatial and temporal dynamics of host parasitoid interaction. New York: Oxford Univ.

Hodek I, Honek A. 1996. Ecology of Coccinellidae. London: Kluwer Academic Publishers. http:// dx.doi.org/10.1007/978-94-017-1349-8.

Holling CS. 1959. Some characteristics of simple types of predation and parasitism. The Canadian Entomologist 91:385-398. http://dx.doi. org/10.4039/Ent91385-7.

Jones DB, Giles KL, Berbearet RC, Royer TA, Elliott NC, Rayton ME. 2003. Functional response of an introduction parasitoid and indigenous parasitoid on greenbug at four temperature. Environmental Entomology 32:425-432. http:// dx.doi.org/10.1603/0046-225X-32.3.425.

Mardiningsih TL, Soetopo D. 1999. Identifikasi kutudaun (Homoptera: Aphididae) pada beberapa jenis tanaman rempah dan obat. Di dalam: Prasadja I, Arifin M, Trisawa IM, Laba, IW, Wikardi EA, Soetopo D, Wiratno, Karmawati E. (Ed.), Peranan Entomologi dalam Pengendalian Hama yang Ramah Lingkungan dan Ekonomis. Prosiding Seminar Nasional (Bogor 16 Februari 1999). pp 595-610. Bogor: Perhimpunan Entomologi Indonesia Cabang Bogor.

Montoya P, Liedo P, Benrey B, Barrera JF, Cancino J, Aluja M. 2000. Functional response and superparasitsm by Diachasmimorpha longicaudata (Hymenoptera: Brachonidae): a parasitoid of fruit flies (Diptera: Tephritidae). Annals of the Entomological Society of America 93:47-54. http:// dx.doi.org/10.1603/0013-8746(2000)093[0047:FR ASBD]2.0.CO;2.

Nelly N, Habazar T, Syahni R, Buchori D, Sahari B. 2005. Tanggap fungsional parasitoid Eriborus argenteopilosus (Cameron) terhadap Crocidolomia pavonana (Fabricius) pada suhu yang berbeda. Jurnal Hayati 12:17-21.

Nelly N, Syam U, Arman D. 2007. Daya predasi kumbang Coccinelid predator hama kutudaun tanaman cabai. Padang: Laporan penelitian Universitas Andalas.

Omkar AP. 2004. Predaceus Coccinellids in India: predator-prey catalogue. Oriental Insects 38:27-61. http://dx.doi.org/10.1080/00305316.2004.1041737 3.

Omkar AP, Bind RB. 2004. Prey quality dependent growth, development and reproduction of a biocontrol agent, Cheilomenes Sexmaculata 
(Fabricius) (Coleoptera: Coccinellidae). Biocontrol Science Technology 14:665-673. http://dx.doi.or g/10.1080/091583150410001682359.

Omkar, Mishra G, Srivastava S, Gupta AK, Singh SK. 2005. Reproductive performance of four aphidophagous ladybirds on cowpea aphid,Aphis craccivora Koch. Journal of Applied Entomology 129:217-220. http://dx.doi.org/10.1111/j.14390418.2005.00953.x.

Rogers D. 1972. Random search and insect population models. Journal of Animal Ecology 41:369-383. http://dx.doi.org/10.2307/3474.
Sharov A. 1996. Functional and numerical response. Available at: http://www.entovt. edu/ sharovPop Ecol/lec10/funcreso.html [accessed 1 November 2010].

Solomon ME. 1949. The Natural control of animal population. Journal of Animal Ecology 18:1-35. http://dx.doi.org/10.2307/1578.

Suyanto A. 1994. Seri pengendalian hama terpadu (PHT): hama sayur dan buah. Jakarta: Penerbit Penebar Swadaya. 